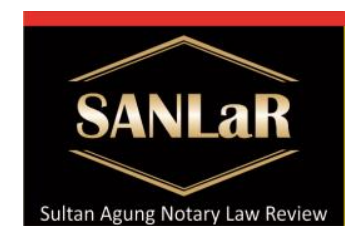

Volume 2 No. 4, December 2020
Sultan Aqung

Notary Law Review

Authority of Notary to Make. . (Aditya Rahma Wicaksono)

\title{
Authority of Notary to Make Roya Concent as in Literature Certificate of Loss
}

\author{
Aditya Rahma Wicaksono*), Lathifah Hanim**) and Soegianto**) \\ *) Students of Master of Notary Law, Universitas Islam Sultan Agung (UNISSULA) \\ Semarang, E-mail: adityarw28@gmail.com \\ ${ }^{* *}$ Lecturer of Master of Notary Law, Universitas Islam Sultan Agung (UNISSULA) \\ Semarang \\ $\left.{ }^{* * *}\right)$ Lecturer of Master of Notary Law, Universitas Islam Sultan Agung (UNISSULA) \\ Semarang
}

Abstract. This study aims to determine and analyze the authority of the notary in making Roya's Concentration Deed and to find out the stages in making the Roya Concentration Deed as a substitute for the lost certificate of mortgage. The approach method in this research uses juridical empiric. The specification of this research is descriptive analysis, the data required includes primary data, secondary data, and tertiary data, the data analysis method uses field research and library research. Based on the research, it is concluded that although the Roya concession deed or the Roya license deed is not clearly regulated, it is related to the authority of the notary in making the deed, because if it is linked in the Roya process to be carried out at the Land Office, the Roya Consent Deed is one of the requirements for implementing Roya. Roya's consent deed is a notary deed that has a position as a substitute for a lost certificate of mortgage, which functions as a condition for registering Roya or withdrawing mortgage rights. Roya consent deed or Roya permit is also a type of partij deed which is a notary made at the request of the parties concerned by accompanying evidence of a letter of loss from the police regarding the loss of a certificate of mortgage, the notary makes a deed of Roya/consent Roya permit to fulfill formal functions a deed, namely to complete or complete a legal act in this case to Roya at the Land Office.

Keywords: Notary; Roya's Consent Deed; Mortgage Certificate.

\section{Introduction}

The existence of a notary has an important role in the banking world, in which case every activity in a banking institution requires a notary to become a partner who helps the process of running the banking institution. One of them is the process of home ownership credit (KPR) or the parties that will guarantee land rights in the form of certificates. Act No. 30 of 2004 as amended by Act No. 2 of 2014 concerning the Position of Notary (hereinafter referred to as UUJN) authorizes notaries to make authentic deeds to guarantee certainty, order and protection of the law. One of the deeds made by a notary is the Roya Consent Deed. The Roya Consent Deed itself is one 
of the authentic deeds made by a Notary at the request of the Bank as a party ${ }^{1}$. Security rights as security rights imposed on land rights as referred to in Act No. 5 of 1960 concerning Basic Agrarian Principles, along with other objects which are an integral part of the land, are for the settlement of certain debts, which gives priority to certain creditors over other creditors. In short, what is meant by Mortgage Rights is collateral rights over land for the settlement of certain debts, which give priority to certain creditors over other creditors. ${ }^{2}$ Based on the Mortgage Rights Law, the process of assigning mortgage rights is carried out in two stages of activity, namely: the stage of granting mortgage rights and the stage of registration of dependents. The Mortgage Rights Law in article 10 paragraph (2) states that the granting of mortgage rights is carried out by making a Deed of Granting Mortgage Rights by the Land Deed Making Official in accordance with the applicable laws and regulations. If the mortgage assignment agreement has been made, the next step is to register the mortgage right at the Land Agency as regulated in Government Regulation Number 24 of 1997 concerning Land Registration. Registration of mortgage rights is carried out through several stages or processes until the certificate of mortgage rights is issued by the Regency/City Land Office as stated in Article 14 of Act No. 4 of 1996 concerning Land Mortgage Rights. The mortgage certificate is issued within seven working days after registration of mortgage rights is carried out ${ }^{3}$. Juridically, there has been a guardianship of the rights of the debtor and creditor which is written in the Mortgage Certificate, as well as the land title certificate will be transferred to the name of the mortgage right holder (creditor). On the land title certificate, the name of the mortgage rights holder (creditor) will be written and the basis for the transfer of rights. The mortgage certificate and land title certificate are then handed over to the mortgage holder or proxy, which usually rests with the creditor. ${ }^{4}$ Abolition of Mortgage Rights based on the provisions of Article 18 paragraph (1) requires Roya of Mortgage Rights. In the legal dictionary, Roya means deletion or deletion. ${ }^{5}$ Roya is the write-off of Mortgage Rights on the land title book and the certificate. Roya is carried out when the debt guaranteed in the principal agreement has been paid off. After the debtor's debt or loan has been paid off, the mortgage is removed by Roya at the Regency/City Land Office. The mortgage certificate is required at the time it is going to be processed or written off and includes a certificate of land rights and a letter of Roya from the creditor that the debtor's debt has been paid off and returns the collateral in the form of a certificate of land rights and a certificate of dependence. ${ }^{6}$ There are times when in practice the mortgage certificate is lost before it is processed due to negligence of the mortgage right holder (creditor), theft, being scattered, or damaged by force majeure.

\footnotetext{
${ }^{1}$ Ignasia Novika Roseno, 2016, Notary Authority in Making Consent Deed Roya, Universitas Airlangga's Thesis, p. abstract.

${ }^{2}$ Rachmadi Usman, SH, 1998, Articles on LAND DEFENSE, Djambat, Jakarta, p. 69,70.

3 Regulation of the State Minister for Agrarian Affairs/Head of the National Land Agency Number 5 of 1996 concerning Registration of Mortgage Rights, article 6 paragraph (1)

4 Law of the Republic of Indonesia Number 4 of 1996 concerning Mortgage Rights to Land and objects related to land (UUHT), article 14 paragraph (4) jopasal 13 paragraph (3)

5JCT simorangkir et al, legal dictionary, Jakarta: Sinar Grafika, p. 150.

6 Rudi Indrajaya and Ika Ikmassari, 2016 Deed Roya Mortgage Permit in lieu of Lost Mortgage Certificate, Jakarta: Visimedia, p. 3
} 
The loss of the mortgage certificate is not only when it is with the mortgage rights holder (creditor) before the debtor's debt is paid off, but can also occur when it is in the hands of the debtor after the debt is paid off, but has not been processed yet. The loss of the mortgage certificate results in unclear bonding of mortgage rights and the position of the parties after the debtor's debt is paid off. In order to explain or provide information regarding the missing Mortgage Certificate, in practice, for example, a notarial deed of collateral concession or concession is made by a notary. Consent deed of mortgage rights is a certificate made by a notary and then given to the Land Agency as a substitute for a lost certificate of mortgage which is a requirement for the mortgage rights process. However, from a normative perspective, the Roya Concentration Deed/Roya Permit specifically is not regulated in any Law or regulation because in government regulation no. 24 of 1997 concerning land registration only regulates the issue of losing land title certificates, but there is no clear regulation regarding the issue of loss of title certificates

\section{Research Methods}

The approach method used in this research is juridical empirical method. This research specification is descriptive analysis. Data collection methods used in this study include primary data and secondary data. In this research data collection effort, there are several techniques used, namely Field Research and Library Research.

\section{Results and Discussion}

The notary's authority in making authentic deeds gives a separate role for each deed he makes, especially in the making of the Roya Consent Deed. In the installation of the Mortgage, it will end with the Roya process. Notary who makes an authentic deed, which means that the deed has an agreement between the two parties. An agreement is a legal relationship regarding property between two parties who promise or are deemed to promise to carry out something or do not do something with the other party having the right to demand the implementation of that promise. ${ }^{7}$ In the agreement, there are conditions for the validity of an agreement or an agreement contained in Article 1320 of the Civil Code, which reads: for the validity of an agreement, four conditions are needed: Agree of those who bind themselves, the ability to make an agreement, a matter certain, a cause that is lawful ${ }^{8}$. There are 2 notary powers that are general and special. In Article 15 paragraph (1) of the Law on Notary Position, it is stated that the authority of a notary is to make deeds in general, where the general authority is:

1. Not excluded from other officials stipulated by law;

2. Regarding deeds that must be made or authorized to make authentic deeds regarding all the actions, agreements, and provisions required by the legal rule or desired by the person concerned;

7 Wirjono Pradjodikoro, 1986, Principles of Agreement Law, Bale Bandung, Bandung, p. 19 8R. Subekti, 1998, Agreement Law, Publisher Intermasa, Jakarta, h. 338 
3. Regarding the legal subject (person or legal entity) for whose interest the deed was made or desired by the interested party. ${ }^{9}$

Article 15 paragraph (2) regulates the special authority of a notary to carry out certain legal actions, namely:

1. Ratify the signature and determine the certainty of the date of the letter under the hand by registering in a special book;

2. Record letters under hand by registering in a special book;

3. Making copies of the originals of the letters under hand in the form of copies containing descriptions as written and described in the letters concerned;

4. Conduct validation of the compatibility of the photocopy with the original letter;

5. Give counseling law in connection with making deeds. ${ }^{10}$

In the event that the notary's authority also makes deeds related to land in Article paragraph (2) letter $f$ The Law on Notary Office gives notaries the authority to make deeds related to land, there are 3 (three) interpretations of the article, including:

1. Notary has taken over all authority of the PPAT into the authority of the Notary or has increased the authority of the Notary.

2. The land sector becomes the authority of the Notary.

3. Still there is no taking from the PPAT or returning of authority to the Notary, both PPAT and Notary have their own authority ${ }^{11}$

4. In relation to the position of a notary who is authorized to make authentic deeds, especially those relating to the transfer of rights to land as stated in Article 15 Paragraph (2) point $f$ of the Law on Notary Position (UUJN) which reads: "authority to make deeds relating to land".

For the implementation of the authentic notary deed maker, it is also related to the position of the PPAT in carrying out legal actions, as PPAT in Article 2 paragraph (2) Government Regulation Number 37 of 1998 states that the legal action concerns:

1. Buy and sell;

2. Exchange;

3. Grant;

4. Entry into the company (Inbreng);

5. Sharing of joint rights;

6. Granting the right to build/use rights over property rights;

7. Granting mortgage rights;

8. Power of attorney to impose mortgage rights.

Based on the Civil Code articles 1866 and HIR 165, a notary deed is a deed made in the form prescribed by law, drawn up by or in front of public officials who are in power for it at the place where the deed was drawn up.

Notary deeds that may be made include:

1. Establishment of a Limited Liability Company (PT), amendments to the Minutes of the General Meeting of Shareholders

2. Foundation establishment

9Habib Adjie, 2014, Indonesian Notary Law, Refika Aditama Bandung, p. 79

$10 \mathrm{lbid}$, p. 81

${ }^{11} \mathrm{lbid}, \mathrm{p} .84$. 
3. Establishment of other business entities

4. Power to sell

5. Lease agreement, sale and purchase agreement

6. Description of inheritance rights

7. Will

8. CV establishment includes changes

9. Debt recognition, credit agreement and provision of mortgage rights

10. Cooperation agreements, work contracts All forms of agreements that are not excluded from other officials

Specifically the Roya Permit Deed or Roya Consent Deed is not regulated in any regulation relating to the making of a Notary deed or deed that may be made by a Notary such as several deeds that are clearly stated as above, but in reality there is a Roya license deed or a consensus on mortgage made by a notary as a substitute for a certificate of mortgage which the certificate holder has declared lost.

According to Notary Wiwik Suhartiwi SH, MH Notary domiciled in the city of Semarang, said that although the Roya permit deed or the consent Roya deed was not clearly regulated, it was related to the notary's authority in making the deed, because if it was linked to the Roya process it would be carried out at the Land Office, the Roya Concentration Deed is one of the requirements to implement Roya. ${ }^{12}$ The reason is that the Roya/Consent Roya permit deed is a substitute for the existence of a lost mortgage certificate which should be attached as a condition for the Roya process at BPN.

What is meant by Notary Wiwik Suhartiwi SH, MH as mentioned above is the authority of the notary in making authentic deeds as stated in Article 15 paragraph (1) Law of Notary Position Number 2 of 2014 which reads, "Notaries are authorized to make authentic Deeds regarding all actions, agreements, and stipulations required by laws and regulations and/or those interested in being stated in an authentic Deed, guaranteeing the certainty of the making date of the Deed, keeping the Deed, providing grosse, copy and quotation of the Deed, all of which as long as the Deed is made or not excluded from other officials or other people determined by law. "

The Roya Concentration Deed or Roya Permit is also a type of Partij Deed which is a notary made at the request of the parties concerned by accompanying evidence of a letter of loss from the police regarding the loss of a certificate of mortgage, the Notary makes a Roya/Consent Roya license deed to fulfill formal functions a deed, namely to complete or complete a legal act in this case to Roya at the Land Office. So it's not only legal actions. So the existence of a deed is a formal requirement for a legal act. ${ }^{13}$

The notary made a deed of consent Roya, license Roya, mortgage as a substitute for a certificate of mortgage which was lost due to government regulation No. 24 of 1997 regarding land registration does not regulate the problem of loss of mortgage certificate clearly only regulates the issue of loss of land title certificate, therefore the task of the notary is to make a deed that is agreed upon by all parties including the

12 Wiwik Suhartiwi SH, MH, Notary/PPAT Semarang City, Notary Office/PPAT Wiwik Suhartiwi $\mathrm{SH}, \mathrm{MH}, 09$ November 2020.

${ }^{13}$ Ibid, 09 November 2020. 
right holder, the Land Agency and the Notary as a condition for do the Roya process at the Land Office.

\section{Closing}

The Roya Concentration Deed or Roya Permit is also a type of Partij Deed which is a notary made at the request of the parties concerned by accompanying evidence of a letter of loss from the police regarding the loss of a certificate of mortgage, the Notary makes a Roya/Consent Roya license deed to fulfill formal functions a deed, namely to complete or complete a legal act in this case to Roya at the Land Office. So it's not only legal actions. So the existence of a deed is a formal requirement for a legal act. Notary as an authorized official in making authentic deeds requires accuracy in making authentic deeds, especially in the Roya Consent Deed so that the contents of the deed are conveyed and understood by the land office in the process of eliminating mortgage rights.

\section{References}

Books:

[1] Adjie, Habib, 2014, Hukum Notaris Indonesia, Refika Aditama Bandung.

[2] Indrajaya, Rudi dan Ika Ikmassari, 2016 Akta Izin Roya Hak Tanggungan sebagai pengganti sertifikat Hak Tanggungan yang Hilang, Jakarta: Visimedia.

[3] Pradjodikoro, Wirjono, 1986, Asas-Asas Hukum Perjanjian, Bale Bandung, Bandung

[4] Roseno, Ignasia Novika, 2016, Kewenangan Notaris Dalam Pembuatan Akta Konsen Roya, Thesis Universitas Airlangga.

[5] Simorangkir, J.C.T. dkk, kamus hukum, Jakarta : Sinar Grafika.

[6] Subekti, R., 1998, Hukum Perjanjian, Penerbit Intermasa, Jakarta.

[7] Usman, Rachmadi,S.H., 1998, Pasal-pasal tentang HAK TANGGUNGAN ATAS TANAH, Djambatan, Jakarta.

Regulation:

[1] Regulation of the State Minister for Agrarian Affairs / Head of the National Land Agency Number 5 of 1996 concerning Registration of Mortgage Rights. 
[2] Law of the Republic of Indonesia Number 4 of 1996 concerning Mortgage Rights on Land and objects related to land (UUHT).

Interview:

Suhartiwi, Wiwik S.H, M.H, Notary / PPAT Semarang City 